\title{
Bactericidal Effect of Different Power Parameters of Potassium-Titanylphosphate Laser on Enterococcus faecalis
}

Dilara ARSLAN ${ }^{1}$ id, Alper KUSTARCI², Cem ÇELIK ${ }^{3}$

${ }^{1}$ Department of Endodontics, İstanbul Aydın University School of Dentistry, İstanbul, Turkey

${ }^{2}$ Department of Endodontics, Akdeniz University School of Dentistry, Antalya, Turkey

${ }^{3}$ Department of Microbiology, Cumhuriyet University School of Medicine, Sivas, Turkey

\section{ABSTRACT}

Objective: The objective of this study was to evaluate the antimicrobial activity of different power settings of potassium-titanyl-phosphate (KTP) laser in experimentally infected root canals.

Methods: A total of 119 freshly extracted human single-rooted teeth with mature apices were selected for study. After preparation and sterilization, the specimens were inoculated with $15 \mu \mathrm{L}$ Enterococcus faecalis for 24 hours at $37^{\circ} \mathrm{C}$. The contaminated roots were divided into five experimental groups ( $1 \mathrm{~W}, 1.5 \mathrm{~W}, 2 \mathrm{~W}, 3 \mathrm{~W}$, and $4 \mathrm{~W}$ KTP laser), one negative control [sodium hypoclorite $(\mathrm{NaOCl})$ ] group, and one positive control (sterile saline (SF)) group of 17 teeth each. Before and after applications in the groups, samples retrieved with sterile paper points from the root canal were transferred to tubes containing $5 \mathrm{~mL}$ of the brain heart infusion broth. Next, $10 \mu \mathrm{L}$ of these suspensions were placed at two different sides of the blood agar medium. Bacterial reduction was counted according to the colony-forming units and data were statistically analyzed using the Kruskal-Wallis and Tukey's tests.

Results: The maximum decrease occurred in the $2.5 \% \mathrm{NaOCl}(100 \% \pm 0.00 \%)$ group. This decrease was followed by decreases in the following KTP laser groups: 4W (94.26\%), 3W (87.98\%), 2W (77.43\%), SF (68.80\%), 1.5W (65.89\%), and 1W (52.08\%). Statistically, the difference between the $1 \mathrm{~W}$ KTP laser group and all groups and the difference between the $2.5 \% \mathrm{NaOCl}$ group and all groups, except the 4W KTP laser group, were found to be significant $(\mathrm{p}<0.05)$.

Conclusion: High-power KTP laser irradiation showed efficient antibacterial activity against E. faecalis.

Keywords: E. faecalis, KTP laser, root canal treatment

\section{Introduction}

The principal role of microorganisms in pulpal and periapical diseases has been demonstrated in previous studies (1-3). The elimination of microorganisms from the root canal system and its three-dimensional (3D) tubular network has been acknowledged as a necessary requirement of endodontic treatment. This goal is usually followed by chemomechanical instrumentation, the use of disinfecting solutions, and the settlement of intracanal medication. Sodium hypochlorite $(\mathrm{NaOCl})$ is the most widely used irrigation solution owing to its proven antimicrobial effectiveness and tissue digestive properties and is considered the gold-standard irrigation solution $(4,5)$. Nevertheless, the complete elimination of microorganisms from the root canals appears to be an impossible task (4). This can be attributed to the complex nature of the root canal anatomy, which includes accessory canals, anastomoses, and fins. The microorganisms are able to diffuse the root dentin up to a depth of more than $1 \mathrm{~mm}$; however, disinfecting solutions achieve a depth of only approximately 100 $\mu \mathrm{m}(6,7)$. Enterococcus faecalis is the most frequently isolated bacteria with treatment failure after root canal treatment (8) that can penetrate to depths between 160 and $1000 \mu \mathrm{m}$ into the lateral dentinal tubules (9). Furthermore, E. faecalis has the ability to produce intra- and extraradicular biofilms (10); hence, it is difficult to disinfect the whole root canal system with the currently used chemomechanical preparations and irrigations. Because of this deficiency in the penetration depth of the disinfecting solutions, microorganisms survive and are a cause of failed endodontic therapy (11).

Cite this article as: Arslan D, Kustarcı A, Çelik C. Bactericidal Effect of Different Power Parameters of Potassium-Titanylphosphate Laser on Enterococcus faecalis. Bezmialem Science 2018; 6: 48-53.

This study was presented at the 1015t FDI Annual World Dental Congress (Agust, 28-31, 2013), istanbul, Turkey. 
The introduction of laser beams in the field of endodontics increased the effectiveness and success rate of root canal treatment because the laser beam delivers the fiber optic effect to the dentinal tubules $(12,13)$. The mission of laser energy could indicate a way to disinfect areas deep within the dentin (14). In previous studies, various laser systems have been evaluated in root canal therapy, and most of them have shown favorable results (15-17). In dentistry, potassium-titanyl-phosphate (KTP) lasers are primarily used for surgical procedures and tooth whitening; however, their use in endodontics is novel $(18,19)$. Schoop et al. (20) showed that the $1 \mathrm{~W}$ power setting appeared to be too low to have an effect on $E$. faecalis, but the number of bacteria decreased when the duration of the KTP laser irradiation or the power level was increased. Kustarci et al. (21) evaluated the antimicrobial activity of the KTP laser at $1.5 \mathrm{~W}$ and found that a the KTP laser at $1.5 \mathrm{~W}$ reduced the E. faecalis bacterial load but could not achieve complete sterilization.

The aim of this study was to evaluate the antimicrobial activity of the KTP laser at various output powers ranging from $1 \mathrm{~W}$ to $4 \mathrm{~W}$ in experimentally contaminated root canals.

\section{Methods}

This study was approved by the Ethics Committee of the University of Cumhuriyet, Sivas, Turkey. Informed consent was obtained from all individual participants included in the study.

\section{Selection and preparation of teeth}

A total of 119 freshly extracted human single-rooted mandibular premolar teeth were used in this study. All teeth were examined using digital periapical radiographs (PR) (Digora; Soredex, Helsinki, Finland) in buccal and proximal directions. The parameters of the PR were $70 \mathrm{kV}, 70 \mathrm{~mA}, 0.07 \mathrm{~s}$, with the angle for the pitch tube perpendicular to the tooth length axis and film and the film parallel to the tooth length axis. Teeth with calcification, open apices, and multiple anatomy were excluded. The selected teeth were mechanically and ultrasonically cleaned and then stored in $\mathrm{SF}$ at $4^{\circ} \mathrm{C}$ until use. The crowns were separated at the level of the cemento-enamel junction with a diamond disk. Root length was standardized at $16 \mathrm{~mm}$. An International Standards Organization (ISO) \#15 K-type file (Denstply Maillefer, Ballaigues, Switzerland) was inserted into the root canal until visible at the apical foramen. The working length of each root canal was then established $1 \mathrm{~mm}$ short of the apical foramen. Gates Glidden burs (Dentsply Maillefer) \#1 to \#4 were used to enlarge the coronal third of the root canals before instrumentation. All canals were instrumented using a traditional step-back technique. The coronal size up to ISO \#60 and apical size up to ISO \#40 K-file were determined. The canals were irrigated with $1 \mathrm{~mL} 2.5 \% \mathrm{NaOCl}$ between each file, and at the end of the instrumentation, the smear layer was removed using 2 $\mathrm{mL} \mathrm{17 \%}$ ethylene diamine tetra acetic acid for 2 minutes and then with $2 \mathrm{~mL} 2.5 \% \mathrm{NaOCl}$. For the final irrigation, $2 \mathrm{~mL}$ distilled water was used, and root canals were then dried with absorbent paper points.

The external surfaces of all roots were covered with nail varnish to prevent microleakage. Standard apical size was achieved using a $15 \mathrm{~K}$-file. A hole was created in a rubber stopper, and roots were fitted into the hole; subsequently, the rubber stopper with the roots was seated into the vial. The entire model was sterilized in ethylene oxide gas for a 12-hour cycle using an Anprolene AN 74C Gas Sterilizer (Andersen Products Inc., Haw River, NC, USA).

\section{Bacterial inoculation}

E. faecalis (American Type Culture Collection, ATCC, 29212) grown in the brain heart infusion broth (BHI; Difco, Detroit, MI, USA) was used. All of the canals were then contaminated with $E$. faecalis. The $0.5 \mathrm{McF}$ arland standard was used to appreciate the broth. A $15 \mu \mathrm{L}$ amount of the bacterial culture was introduced into the root canal using a sterile micropipette and then stored for $24 \mathrm{~h}$ at $37^{\circ} \mathrm{C}$. The contaminated roots were then randomly divided into seven groups ( 5 experimental, 2 control) of 17 samples each.

\section{Experimental and control groups}

Laser groups (1-5): The SmartLite KTP laser (Deka, Calenzano, Italy) system was used during the irradiation procedure. Application parameters were set as Group 1: $1 \mathrm{~W}, 5.33 \mathrm{~J} / \mathrm{cm}^{2}$; Group 2: 1.5W, $7.52 \mathrm{~J} / \mathrm{cm}^{2}$; Group 3: $2 \mathrm{~W}, 10.3 \mathrm{~J} / \mathrm{cm}^{2}$; Group 4: $3 \mathrm{~W}, 15.5 \mathrm{~J} / \mathrm{cm}^{2}$; and Group 5: $4 \mathrm{~W}, 20.1 \mathrm{~J} / \mathrm{cm}^{2}$. For all groups, n: 17, Ton: $10 \mathrm{~ms}$, and Toff: $50 \mathrm{~ms}$. During laser irradiation, the optical fiber optic cable (diameter of $200 \mu \mathrm{m}$ ) was inserted into the canals passively to within $1 \mathrm{~mm}$ of the apex then moved coronally with a spiral movement. at a duration of apical and middle third roots for 3 seconds and coronal third of roots for 4 seconds. This procedure was repeated three times on each sample with a 20 -second cooling time between each irradiation.

Group 6 (Negative control): The root canals were irrigated with $2 \mathrm{~mL}$ of $2.5 \% \mathrm{NaOCl}$ solution using a $2.5-\mathrm{mL}$ plastic syringe with a 27 -gauge needle. Root canals were exposed to the solution for 10 minutes.

Group 7 (Positive control): The root canals were irrigated with $2 \mathrm{~mL}$ of $0.9 \%$ SF solution.

\section{Bacterial evaluation}

To remove the bacteria from root canals, each canal was washed with $1 \mathrm{~mL}$ of $0.9 \% \mathrm{SF}$ solution; subsequently, size 40 sterile paper points were held for 1 minute inside the canals before and after the experimental and control group procedures. The paper points were relayed to tubes that contained $5 \mathrm{~mL}$ of the BHI broth. Tubes were vortexed for 5 minutes, and $10 \mathrm{~mL}$ of the suspension was inoculated onto blood agar plates. The blood agar plates were divided into 2 parts: one for pre-treatment inoculation and the other for post-treatment inoculation. The blood agar plates were incubated at $37^{\circ} \mathrm{C}$ for $24 \mathrm{~h}$. 


\section{Statistical analysis}

Bacterial reduction was investigated according to the colonyforming units (CFU), and the results were analyzed using Kruskal-Wallis and Tukey's post hoc tests. The significance level was set at $\mathrm{p}=0.05$. All statistical analyses were performed using the SPSS 20.0 software (IBM SPSS Statistics; Armonk, NY, USA).

\section{Results}

Bacterial counts of each group before (C1) and after (C2) treatments and bacterial reductions $[\mathrm{C} 1 / \mathrm{C} 2(\%)]$ in different groups are presented in Table 1 and Figure 1. A bactericidal

Table 1. Bacterial counts (CFU) from the experimentally infected root canals, laser and control groups

\begin{tabular}{|c|c|c|}
\hline Groups & Noun & $\begin{array}{l}\text { Bacterial Reduction } \\
{[\mathrm{C} 1 / \mathrm{C} 2(\%)]} \\
\overline{\mathrm{X}} \pm \text { SD }\end{array}$ \\
\hline Group 1 (1W) & 17 & $52.08 \pm 20.46^{a}$ \\
\hline Group 2 (1.5W) & 17 & $65.89 \pm 12.29^{b}$ \\
\hline Group 3 (2W) & 17 & $77.43 \pm 4.73^{b}$ \\
\hline Group 4 (3W) & 17 & $87.98 \pm 3.80^{\mathrm{b}}$ \\
\hline Group 5 (4W) & 17 & $94.26 \pm 4.09^{b, c}$ \\
\hline Group 6 (2.5\% NaOCl) & 17 & $100 \pm 0.00^{c}$ \\
\hline Group 7 (SF) & 17 & $68.80 \pm 16.9^{b}$ \\
\hline \multicolumn{3}{|c|}{$\begin{array}{l}\text { Different superscript letters represent significant differences } \\
\text { CFU: colony-forming units; C1: before KTP laser irradiation and irrigatior } \\
\text { solution; C2: after KTP laser irradiation and irrigation solution }\end{array}$} \\
\hline
\end{tabular}

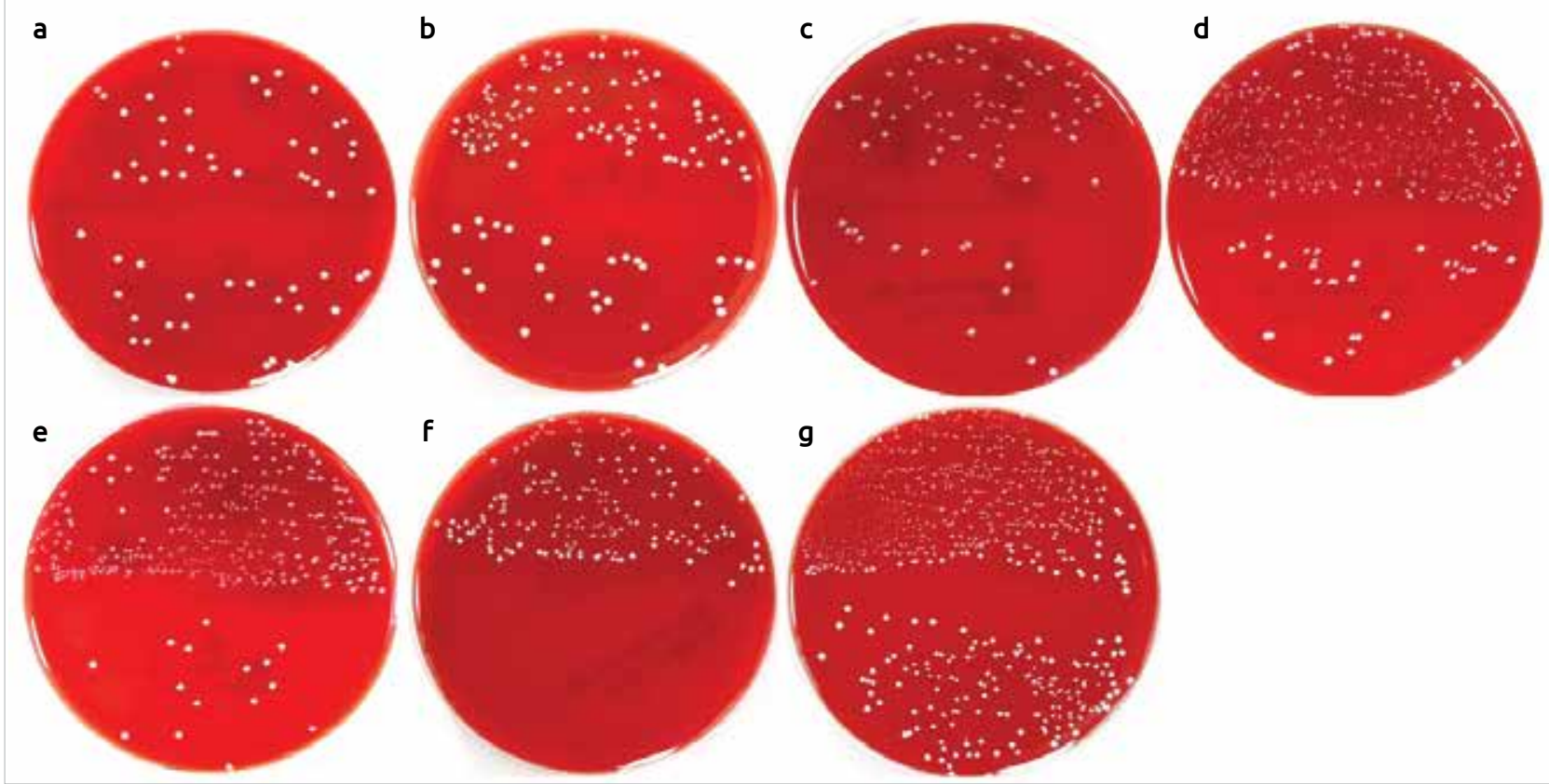

effect was observed for all groups. The maximum decrease occurred in the group where $2.5 \% \mathrm{NaOCl}(100 \% \pm 0.00 \%)$ was employed. This decrease was followed by decrease in the following groups: $4 \mathrm{~W}(94.26 \% \pm 4.09 \%), 3 \mathrm{~W}(87.98 \% \pm 3.80 \%)$, $2 \mathrm{~W} \quad(77.43 \% \pm 4.73 \%), \quad$ SF $\quad(68.80 \% \pm 16.97 \%), \quad 1.5 \mathrm{~W}$ $(65.89 \% \pm 12.29 \%)$, and $1 \mathrm{~W}(52.08 \% \pm 20.46 \%)$. The $2.5 \%$ $\mathrm{NaOCl}$ solution used on the negative control group made a successful elimination. Interestingly, the bactericidal activity of SF used in the positive control was higher than $1 \mathrm{~W}, 1.5 \mathrm{~W}$ KTP laser groups. Statistically, the difference between $1 \mathrm{~W}$ KTP laser group and all groups, and the difference between the group that $2.5 \%$ of $\mathrm{NaOCl}$ and all groups except of $4 \mathrm{~W}$ KTP laser group were found significant $(\mathrm{p}<0.05)$.

\section{Discussion}

E. faecalis, a Gram-positive anaerobic coccus, was chosen as the test organism for this study because it is the most commonly isolated bacterium in cases of inconclusive endodontic therapy (11). It has been shown that E. faecalis is extremely resistant to various chemical disinfectants and intracanal medicaments (22). Its high prevalence is due to its virulence factors as penetrated to dentinal tubules, adhesion to collagen, and capacitance against inadequate nutritional cases. In addition, it is recognized for its ability to form biofilms, which makes it extremely difficult to control (23).

Clinically, $\mathrm{NaOCl}$ is known worldwide as an intracanal disinfectant irrigant for endodontic therapy owing to its organic tissue dissolving ability and its broad antimicrobial activity (24). Shih et al. (25) noted that a $5.25 \% \mathrm{NaOCl}$ irrigant was a powerful germicide at this concentration. It

Figure 1. a-g. Bacteria before and after treatment blood agar plates view. (a) $1 \mathrm{~W}$ KTP laser, bacterial reduction $52 \%$. (b) $1.5 \mathrm{~W}$ KTP laser, bacterial reduction $65 \%$. (c) 2 W KTP laser, bacterial reduction $77 \%$ (d) 3 W KTP laser, bacterial reduction $87 \%$ (e) $4 \mathrm{~W}$ KTP laser, bacterial reduction $94 \%$. (f) $2.5 \% \mathrm{NaOCl}$ irrigation, bacterial reduction $100 \%$. (g) $\mathrm{NaCl}$ irrigation, bacterial reduction $68 \%$ 
has been reported that high-concentration solutions when flashed into the periapical tissues or leaked by the rubber dam during irrigation lead to tissue damage (26). Furthermore, a $5.25 \% \mathrm{NaOCl}$ solution considerably reduces the elastic modulus and flexural strength of dentin (27). Siqueira et al. (28) evaluated the antimicrobial efficacy of varying concentrations of $\mathrm{NaOCl}$ solutions $(1 \%, 2.5 \%$, and $5.25 \%$ $\mathrm{NaOCl}$ ) in vitro. They found that there was no significant difference among the three $\mathrm{NaOCl}$ solutions tested and that all test solutions were more effective than the control solutions (SF). In addition, Abdullah et al. (29) showed that treatment by $3 \% \mathrm{NaOCl}$ irrigation for 2 minutes achieved complete elimination of the microorganisms. Considering these factors, this study used a $2.5 \% \mathrm{NaOCl}$ solution for 10 minutes; rinsing with $\mathrm{NaOCl}$ caused a greater reduction of viable bacteria when compared with the laser treatment. No bacteria samples were detected on any of the blood agar plates. These results were found to be in accordance with previous studies.

Sodium hypochlorite could not penetrate deeply enough into the dentin layer and could not exterminate bacteria in the deep dentin layers (7). Although bacteria can move 1.1 $\mathrm{mm}$ along the dentin tubules, disinfectant solutions cannot pass beyond $0.13 \mathrm{~mm}$ (6). With the introduction of laser energy and devices that moved energy into the root canal, the endodontic procedure was enriched and avoided the disadvantages of conventional endodontic cleaning procedures, thereby greatly raising the probability of successful treatment. Vaarkamp et al. (12) and Odor et al. (13) suggested that the dentinal tubules assumed the role of light conductors; in this way, the laser light is moved to the remote dentin areas. In comparison with chemical irrigants, lasers are markedly more effective in reaching deep dentin layers. In recent years, the bactericidal effects of various laser systems, such as the neodymium:yttrium-aluminum-garnet laser (Nd:YAG), the diode laser, erbium:yttrium-aluminumgarnet (Er:YAG) laser, and the erbium:chromium:yttriumscandium-gallium-garnet (Er,Cr:YSGG) laser, have been investigated for use in root canal treatment; many studies examining the antibacterial activity of these lasers indicated success $(16,20,21,30,31)$.

The most serious concern in the use of lasers in endodontics is the possible thermal effects in vivo of a laser on the pulp and periodontal tissues. During root canal treatment, although the laser is directly interacting with dentin, this interaction has the potential to reach up into the periodontal tissues by spreading the heat generated as a result of the interaction (20). By analyzing the literature, it can be seen that there are a very limited number of studies on KTP lasers' bacterial effects; in addition, the KTP laser was used at limited power levels and for limited periods of time in these studies $(13,20,21)$.

Nammour et al. (32), in their study, examined the ideal conditions for use of the KTP-Nd:YAG laser in root canal treatment. They showed that the use of KTP-Nd:YAG was safe, and although the output power was high ( $4 \mathrm{~W})$, the increase in temperature did not exceed critical values at the root surface. Taking this into account, the present in vitro study was performed to evaluate the bactericidal effect of the KTP laser at five different output powers ( $1 \mathrm{~W}, 1.5 \mathrm{~W}, 2 \mathrm{~W}, 3 \mathrm{~W}$, and $4 \mathrm{~W})$ for 10 seconds, $3 \times$, with a 20 -second cooling time. The percentage of bacterial reduction was as follows: $1 \mathrm{~W}: 52.08 \% \pm 20.46 \%$; $1.5 \mathrm{~W}: \quad 65.89 \% \pm 12.29 \%$; SF: $68.80 \% \pm 16.97 \%$; $2 \mathrm{~W}:$ $77.43 \% \pm 4.73 \%$; $3 \mathrm{~W}: 87.98 \% \pm 3.80 \%$; $4 \mathrm{~W}: 94.26 \% \pm 4.09 \%$; and $2.5 \%$ of $100 \% \mathrm{NaOCl}$.

Schoop et al. (20) evaluated the antibacterial effect of the KTP laser on the dentin disc and observed minor changes in the bacterial count at a $1 \mathrm{~W}$ power setting KTP laser. However, when they used the higher setting of $1.5 \mathrm{~W}$, no growth was observed in half of the 20 samples. In the current study, when $1 \mathrm{~W}$ output power was used, a more than $50 \%$ reduction rate was seen in bacteria; when $1.5 \mathrm{~W}$ was used, the reduction rate was more than $65 \%$; and when $4 \mathrm{~W}$ was used, the reduction rate was more than $90 \%$. In addition, no growth was observed in some samples in $4 \mathrm{~W}$ group. In our study, we found no growth results in the higher output, and we thought that these differences occurred because of the different interactions with the target tissues. The effectiveness of lasers are based on many factors such as power settings, absorption of light in the tissues, time of exposure of the anatomy of the root canal, and the laser tip-to-target distance and angle (33).

Kustarci et al. (21) investigated the antimicrobial activity of the KTP laser in contaminated root canals. They irradiated the root canals at $1.5 \mathrm{~W}, 10 \mathrm{~J} / \mathrm{cm}^{2}$, with the KTP laser (5 seconds, $5 \times$, with 15 -second intervals). In their study, total elimination was achieved in the $2.5 \% \mathrm{NaOCl}$ group. The KTP laser irradiation resulted in a significant decrease of the E. faecalis bacterial load; however, laser irradiation could not achieve complete sterilization. These results demonstrated that chemomechanical instrumentation is the basic principle for the sterilization of root canals and that the laser is useful as an adjunct method. In our study, when the $1.5 \mathrm{~W}$ laser was used, a more than $65 \%$ success was achieved; however, it did not provide a complete sterilization. These results are consistent with the results of Kustarci et al. (21).

Meire et al. (19) evaluated the effectiveness of the KTP laser applications against $E$. faecalis on in vitro bacterial suspensions and in an infected ex vivo tooth model and found no significant effect on $E$. faecalis from using the KTP laser in vitro. These results can be explained by the KTP laser wavelengths, which are less absorbent in water. Transmission occurred rather than absorption and E. faecalis cells continued to survive. Thus, we preferred to work with the infected tooth model. The KTP laser used $1 \mathrm{~W}$ for 5 seconds, $5 \times$, at 20 -second intervals (total energy $25 \mathrm{~J} / 10$ sample $=2.5 \mathrm{~J}$ per canal) and appeared to be too low to affect the viability of the $E$. faecalis cells. However, in our study, at $1 \mathrm{~W}$ output power $(5.33$ $\mathrm{J} / \mathrm{cm}^{2}$ ), a bacterial reduction of $52.08 \% \pm 20.46 \%$ was suggest- 
ed; we believe that the amount of total energy accumulated in the tissue explained these differences.

Romeo et al. (34) evaluated the antibacterial activity of KTP laser irradiations associated and compared the results with those of the conventional procedures. They used extracted teeth infected with $E$. faecalis biofilms. The KTP laser used 2.5W, Ton $35 \mathrm{~ms}$, and Toff $50 \mathrm{~ms}$ ( 5 seconds, $3 \times$, at 5 -second intervals). The results of their study showed a reduction in the number of adherent $E$. faecalis in biofilm at various levels [only mechanical treatment $(\mathrm{MT})<\mathrm{MT}$ with KTP laser $<$ MT with $5 \% \mathrm{NaOCl}<\mathrm{MT}$ with $5 \% \mathrm{NaOCl}$ and KTP laser]. According to the results in the mechanical treatment groups, bacterial reduction was also found to be the lowest, whereas it was highest in $\mathrm{MT}$ with $5 \% \mathrm{NaOCl}$ and the KTP laser group. Chemomechanical treatment, coupled with laser treatment, prevented the majority of the populations in root canals. In our study, we used $2.5 \% \mathrm{NaOCl}$ alone, and $100 \%$ bacterial reduction was achieved. In the laser groups, $2 \mathrm{~W}$ alone achieved a $77.43 \%$ success and $3 \mathrm{~W}$ alone achieved an $87.98 \%$ success, but total disinfection could not be achieved in the canal.

In this study, superior antibacterial effects were obtained using KTP laser on the canal wall, although bacteria remaining in the deeper dentin were not observed and determined because of limitations of the bacterial analysis technique used in our study. Because of the methodological limitations, further in vivo and in vitro investigations are necessary to establish the antimicrobial activity on the entire dentin.

\section{Conclusion}

High-power KTP laser irradiation showed efficient antibacterial activity against E. faecalis; however, we did not achieve total elimination. KTP laser irradiation could be added to conventional endodontic procedures, particularly after the final $\mathrm{NaOCl}$ irrigation.

Ethics Committee Approval: Ethics committee approval was received for this study from the Ethics Committee of Cumhuriyet University.

Informed Consent: Written informed consent was obtained from all the patients who participated in this study.

Peer-review: Externally peer-reviewed.

Author Contributions: Concept - A.K.; Design - A.K.; Supervision - D.A.; Resource - C.Ç.; Materials - D.A., C.Ç.; Data Collection and/or Processing - D.A., C.Ç.; Analysis and/or Interpretation - D.A., A.K.; Literature Search - D.A.; Writing - D.A.; Critical Reviews - A.K.

Conflict of Interest: No conflict of interest was declared by the authors.

Financial Disclosure: This study was supported by a grant given by Cumhuriyet University Scientific Research Project Coordination Center, Sivas, Turkey (Number of protocol 96).

\section{References}

1. Kakehashi S, Stanley HR, Fitzgerald RJ. The effects of surgical exposures of dental pulps in germ-free and conventional laboratory rats. Oral Surg Oral Med Oral Pathol 1965; 20: 340-9. [CrossRef]

2. Moller AJ, Fabricius L, Dahlen G, Ohman AE, Heyden G. Influence on periapical tissues of indigenous oral bacteria and necrotic pulp tissue in monkeys. Scand J Dent Res 1981; 89: 475-84. [CrossRef]

3. Sundqvist G. Ecology of the root canal flora. J Endod 1992; 18 : 427-30. [CrossRef]

4. Bystrom A, Sundqvist G. Bacteriologic evaluation of the efficacy of mechanical root canal instrumentation in endodontic therapy. Scand J Dent Res 1981; 89: 321-8. [CrossRef]

5. Sjogren U, Figdor D, Persson S, Sundqvist G. Influence of infection at the time of root filling on the outcome of endodontic treatment of teeth with apical periodontitis. Int Endod J 1997; 30: 297-306. [CrossRef]

6. Kouchi Y, Ninomiya J, Yasuda H, Fukui K, Moriyama T, Okamoto H. Location of Streptococcus mutans in the dentinal tubules of open infected root canals. J Dent Res 1980; 59: 203846. [CrossRef]

7. Berutti E, Marini R, Angeretti A. Penetration ability of different irrigants into dentinal tubules. J Endod 1997; 23: 725-7. [CrossRef]

8. Sedgley CM, Lennan SL, Clewell DB. Prevalence, phenotype and genotype of oral enterococci. Oral Microbiol and Immunol 2004; 19: 95-101. [CrossRef]

9. Peters LB, Wesselink PR, Moorer WR. Penetration of bacteria in bovine root dentine in vitro. Int Endod J 2000; 33: 28-36. [CrossRef]

10. Noiri Y, Ehara A, Kawahara T, Takemura N, Ebisu S. Participation of bacterial biofilms in refractory and chronic periapical periodontitis. J Endod 2002; 28: 679-83. [CrossRef]

11. Love RM. Enterococcus faecalis--a mechanism for its role in endodontic failure. Int Endod J 2001; 34: 399-405. [CrossRef]

12. Vaarkamp J, ten Bosch JJ, Verdonschot EH. Propagation of light through human dental enamel and dentine. Caries Res 1995; 29: 8-13. [CrossRef]

13. Odor TM, Chandler NP, Watson TF, Ford TR, McDonald F. Laser light transmission in teeth: A study of the patterns in different species. Int Endod J 1999; 32: 296-302. [CrossRef]

14. Bergmans L, Moisiadis P, Teughels W, Van Meerbeek B, Quirynen $\mathrm{M}$, Lambrechts $\mathrm{P}$. Bactericidal effect of $\mathrm{Nd}$ : YAG laser irradiation on some endodontic pathogens ex vivo. Int Endod J 2006; 39: 547-57. [CrossRef]

15. Schoop U, Kluger W, Moritz A, Nedjelik N, Georgopoulos A, Sperr W. Bactericidal effect of different laser systems in the deep layers of dentin. Lasers Surg Med 2004; 35: 111-6. [CrossRef]

16. Pirnat $S$, Lukac M, Ihan A. Study of the direct bactericidal effect of Nd: YAG and diode laser parameters used in endodontics on pigmented and nonpigmented bacteria. Lasers Med Sci 2011; 26: 755-61. [CrossRef]

17. Gutknecht N, van Gogswaardt D, Conrads G, Apel C, Schubert $\mathrm{C}$, Lampert F. Diode laser radiation and its bactericidal effect in root canal wall dentin. J Clin Laser Med Surg 2000; 18: 57-60.

18. Romeo U, Palaia G, Del Vecchio A, Tenore G, Gambarini G, Gutknecht N, et al. Effects of KTP laser on oral soft tissues. An in vitro study. Lasers Med Sci 2010; 25: 539-43. [CrossRef]

19. Meire MA, De Prijck K, Coenye T, Nelis HJ, De Moor RJ. Effectiveness of different laser systems to kill Enterococcus faecalis in aqueous suspension and in an infected tooth model. Int Endod J 2009; 42: 351-9. [CrossRef] 
20. Schoop U, Kluger W, Dervisbegovic S, Goharkhay K, Wernisch $\mathrm{J}$, Georgopoulos A, et al. Innovative wavelengths in endodontic treatment. Lasers Surg Med 2006; 38: 624-30. [CrossRef]

21. Kustarci A, Sumer Z, Altunbas D, Kosum S. Bactericidal effect of KTP laser irradiation against Enterococcus faecalis compared with gaseous ozone: An ex vivo study. Oral Surg Oral Med Oral Pathol Oral Radiol Endod 2009; 107: 73-9. [CrossRef]

22. Pinheiro ET, Gomes BP, Ferraz CC, Sousa EL, Teixeira FB, Souza-Filho FJ. Microorganisms from canals of root-filled teeth with periapical lesions. Int Endod J 2003; 36:1-11. [CrossRef]

23. Kishen A, George S, Kumar R. Enterococcus faecalis-mediated biomineralized biofilm formation on root canal dentine in vitro. J Biomed Mater Res A 2006; 77: 406-15. [CrossRef]

24. Spano JC, Barbin EL, Santos TC, Guimaraes LF, Pecora JD. Solvent action of sodium hypochlorite on bovine pulp and physico-chemical properties of resulting liquid. Braz Dent J 2001; 12: 154-7.

25. Shih M, Marshall FJ, Rosen S. The bactericidal efficiency of sodium hypochlorite as an endodontic irrigant. Oral Surg Oral Med Oral Pathol 1970; 29: 613-9. [CrossRef]

26. Hulsmann M, Hahn W. Complications during root canal irrigation--literature review and case reports. Inl Endod J 2000; 33: 186-93. [CrossRef]

27. Sim TP, Knowles JC, Ng YL, Shelton J, Gulabivala K. Effect of sodium hypochlorite on mechanical properties of dentine and tooth surface strain. Int Endod J 2001; 34: 120-32. [CrossRef]
28. Siqueira JF, Jr., Rocas IN, Favieri A, Lima KC. Chemomechanical reduction of the bacterial population in the root canal after instrumentation and irrigation with $1 \%, 2.5 \%$, and $5.25 \%$ sodium hypochlorite. J Endod 2000; 26: 331-4.

29. Abdullah M, Ng YL, Gulabivala K, Moles DR, Spratt DA. Susceptibilties of two Enterococcus faecalis phenotypes to root canal medications. J Endod 2005; 31: 30-6. [CrossRef]

30. Dewsnup N, Pileggi R, Haddix J, Nair U, Walker C, Varella CH. Comparison of bacterial reduction in straight and curved canals using erbium, chromium: Yttrium-scandium-gallium-garnet laser treatment versus a traditional irrigation technique with sodium hypochlorite. J Endod 2010; 36: 725-8. [CrossRef]

31. Gutknecht N, Franzen R, Schippers M, Lampert F. Bactericidal effect of a 980-nm diode laser in the root canal wall dentin of bovine teeth. J Clin Laser Med Surg 2004; 22: 9-13. [CrossRef]

32. Nammour S, Kowaly K, Powell GL, Van Reck J, Rocca JP. External temperature during KTP-Nd: YAG laser irradiation in root canals: An in vitro study. Lasers Med Sci 2004; 19: 27-32. [CrossRef]

33. Dederich DN, Zakariasen KL, Tulip J. Scanning electron microscopic analysis of canal wall dentin following neodymiumyttrium-aluminum-garnet laser irradiation. J Endod 1984; 10: 428-31. [CrossRef]

34. Romeo U, Palaia G, Nardo A, Tenore G, Telesca V, Kornblit R, et al. Effectiveness of KTP laser versus $980 \mathrm{~nm}$ diode laser to kill Enterococcus faecalis in biofilms developed in experimentally infected root canals. Aust Endod J 2015; 41: 17-23. [CrossRef] 